\title{
FEMINIST PEDAGOGY AS A NEW INITIATIVE IN THE EDUCATION OF SOUTH AFRICAN TEACHERS
}

Author:

Sonja Schoeman ${ }^{1}$

\section{Affiliation:}

'Department of Curriculum and Instructional Studies, Unisa PO Box 392, Unisa, 0003, South Africa

\section{Correspondence to:} Sonja Schoeman

Email:

schoes@unisa.ac.za

\section{Postal address:}

PO Box 392, Unisa, 0003 , South Africa

Dates:

15 Dec 2015

How to cite this article: Schoeman, S., 2015.

"Feminist pedagogy as a new initiative in the education of South African teachers". KOERS - Bulletin for Christian Scholarship, 80(4). Available at: http:// dx.doi.org/10.19108/ koers.80.4.2215

\section{Copyright:}

(c) 2015. The Author(s).

Published under the

Creative Commons

Atribution License.
Feministiese pedagogie as 'n nuwe inisiatief in die opleiding van Suid-Afrikaanse onderwysers. Daar is nog nie baie in Suid-Afrika oor feministiese pedagogie en onderwysersopleiding gepubliseer nie. Die doel van hierdie artikel is om bogenoemde aan die Suid-Afrikaanse onderwyskorps bekend te stel, waar dit nog nie ' $n$ veilige tuiste geniet nie. Die probleem van die studie fokus op twee aspekte: die gebrek aan 'n alternatiewe onderwysersopleiding perspektief en ervaring in Suid-Afrika, en die moontlikheid van onderwysersopleiding vir die nuwe genderorde, en 'n oplewing in die genderdebat. Die doel van die studie is om te besin oor die patriargale onderwysersopleidingsmodelle, ongekwalifiseerde onderwysers se begrip van die magsverhoudinge in die onderwys te bevorder, en voorbrand te maak vir die moontlike insluiting van feministiese pedagogie in onderwysersopleidingsprogramme. 'n Kwalitatiewe konseptuele dokument-analise is as navorsingsontwerp gebruik. Die artikel is afgesluit met 'n eksemplaar onderwysersopleidingsmodule waarin die student-onderwysers aan 'n kritiese studie van leer om te onderrig (feministiese pedagogie), en ' $\mathrm{n}$ feministiese klaskameromgewing voorgestel word.

Sleutelwoorde: post-strukturalisme, feministiese pedagogie en praktyk, agente vir sosiale verandering, gekonnekteerde en gekonstruktureerde kennis, plurale interpretasie, gender onsigbaarheid en stereotipering

Not much has been published about feminist pedagogy and teacher education in South Africa. The purpose of this article is to introduce the above to the South African education fraternity, where it has not yet found a comfortable home. The problem of the study focuses on two issues: the lack of an alternative teacher education perspective and experience in South Africa, and the possibility of teacher education for the new gender order, and a revival of the gender equity debate. The purpose of the study is to reflect on the gendered (patriarchal) teacher education models, enhance the pre-service teachers' understanding of the power relations in education, and argue the case for the inclusion of feminist pedagogy in teacher education programmes. A qualitative conceptual document analysis was used as research design. The article is concluded with an exemplar teacher education module in which student teachers are introduced to a critical study of learning to teach (feminist pedagogy), and a feminist classroom setting.

Keywords: post-structuralism, feminist pedagogy and practice, agents of social change, connected and constructed knowledge, plural interpretation, gender invisibility and stereotyping 
The author declares that she has no financial or personal relationship(s) that may have inappropriately influenced her in writing this article

\section{INTRODUCTION}

Globally, teacher education is subjected to perennial attention and critique. Teacher educators who aspire to the inclusion of feminist pedagogy in initial teacher education programmes often embrace this as an opportunity to involve academics from all educational disciplines in the debate. According to Cohee (2004:1), co-editor of the journal Feminist Teacher, the debate focuses primarily on the argument that the academy is a place of pure knowledge, and adding feminism to the mix will politicize education that is inherently not political. During a teacher educator workshop entitled, Restructuring a Syllabus argument that the academy is anything but apolitical, and using feminism in teaching merely makes the politics somewhat feminism in teaching merely makes the politics somewhat
clearer (Cohee 2004:1). During the 2013 Annual International Conference on Diversity in Organizations, Communities \& Nations, feminist teacher educators from a variety of teacher Nations, feminist teacher educators from a variety of teacher
education disciplines have spent a substantial amount of time discussing the positive ways (activism, community building, empowerment, voice privileging) in which the theory and practice of their modules have changed over time trying out the principles of feminist pedagogy (Author 2013: Personal experience.

\section{PROBLEM STATEMENT}

The problem of this study focuses on two issues: firstly, the lack of an alternative teacher education perspective and experience in South Africa compared to the traditional secondly, the possibility of the inclusion of feminist pedagogy in South African initial teacher education programmes to promote the new gender order, and revitalize the gender equity and social justice debate in education. According to Apple (1988:4, 6), Freire (1984:68), hooks (1994:6, 10), McLaren (in Steiner, Kranak, McLaren \& Baruth 2000:22) and Shor (1996:78-89), the school curriculum is far from being neutral. Fardon (2007:6-15), Fardon and Schoeman (2010:307-323) and Robinson (2003:32) highlighted the male-orientation of the school subjects and the existence of patriarchal power relations and inequality in South African classrooms. Although research findings published since 1994 (a) in recently published school sources, the subtle gender messages in the texts are still remaining (Fardon \& Schoeman, 2010:307-323; Schoeman 2012:541-550).

Teachers are in terms of the official curriculum and policy documents expected to infuse social justice and human rights in their classroom teaching and learning by developing the learners awareness of diversity and the remaining patriarchal power relations in the prescribed learning materials and pedagogy (Department of Basic Education 2011:7). Lather (1991:82) and Weiner (2004:10) recommended that any remaining inaccessible power realms in the official school subjects may be addressed by employing feminist (poststructuralist) pedagogy to nurture learners' critical awareness ed their ow and ochers' subordinated positions within existin 1994:11-15). Teachers also tend to teach as they them:i; Robertso taught and for this reason teacher educators have to carefully tansider the pedagoses that they use in preparing new consider the pedagogies that they use in preparing new teachers who will soon be teaching South Africa's youth who (Department of Basic Education 2011:7). One way to break the cycle of male-dominated hierarchical pedagogies is to prepare teachers who have learned to use feminist pedagogy, and who can change classroom methods to recognize the importane of the changing role and authority of the teacher, the value of personal and professional experience, and the need for a major shift in the balance between the affective and intellectual in the classroom (Weiner 2004:10).

\section{RESEARCH QUESTION}

A descriptive research question was formulated for the study, namely How can the South African teacher education system be transformed to educate pre-service secondary school teachers to be agents of social change (as connected and constructed knowers) who will educate learners to identify gender bias
devices of hegemonic discourse, and open up space for plura interpretation and gender-fair perceptions?

\section{PURPOSE OF THE STUDY}

Given the above deliberation and the fact that two-thirds of the teachers in South African public schools are women the purpose of this study is to put forward a new initiative in the education of pre-service secondary school teachers for them to become agents of social change in terms of gender invisibility and/or stereotyping in school knowledge, gender structure, gender symbolism, and individual gender in education (Arend 2007:1; Britzman 2003:127; Fardon 2007:15 Weiner 2004:10). To this end, the purpose of the study is to challenge the traditional and more controversial critica reformulations of teacher education knowledge to move beyond the 'broken images' (gender invisibility and stereotyping introduce the central tenets of feminist teacher education (poststructuralism, feminism, feminist post-structuralism, critical pedagogy and feminist pedagogy) to enhance pre-service teachers understanding of the power relations in which the will work without being overwhelmed by them; and argue the case for the inclusion of a new pedagogy (feminist pedagogy) 作 achieve

\section{RESEARCH METHODOLOGY AND ETHICAL \\ CONSIDERATIONS}

The research design of the study was a qualitative conceptua document analysis. A literature review of the current, and not so current, yet still sufficiently relevant literature appropriate to the topic of the study was conducted. The informatio for the study was gathered by means of a survey of a variet of written sources, and the deconstruction of the identified concepts (content). The researcher critically engaged with the information to contribute to the existing body of knowledge and understanding of the phenomena related to teacher education from a feminist perspective.

Content analysis was used to analyse the books, conference proceedings, electronic documents, journal articles, and official proceeding, elctronic documents, ournal articles, andofficial and summarse the messages of the sources an inductive and iterative process was used. The similarities and differences in the consulted texts that would corroborate and disconfirm the research question and purpose of the study were identified (Maree, Cresswell, Ebersöhn, Eloff, Ferreira, Ivankova, Jansen, Van Niewenhuis, Pietersen, Plano Clark \& Van der Westhuizen 2012:70-71). The results of the content anan der Westhuizen according to the following themes: the theoretical framework according to the following themes: the theoretical framework of the study (feminist post-structuralism), the relation between feminist post-structuralism and education (critical pedagogy, education system (feminist teacher education).

During the review of the literature, the researcher guarded against selectivity, the misinterpretation of ideas, and the selective interpretation of content to suit her argument (De Vos, Strydom, Fouché \& Delport 2011:56-69).

\section{REVIEW OF THE LITERATURE}

Theoretical framework of the study: feminist post structuralism

Paulston and Liebman's (1996:13-14) conceptual cartography was used to identify the most appropriate theoretical framework for the study. According to the map, the most suitable theoretical framework for the study was identified as feminist poststructuralism. Any clarification of the concept feminist poststructuralism should start with reference to post-structuralism. At its National Gender Summit of 2014, the South African Commission for Gender Equality reported that gender issues are still present in South Africa's institutions, and recommended post-structuralism to address the issues within the discourse in language which offers limited subject identities to individuals (Gouws \& Hassim 2014:2-4). Branston and Stafford (2001:27), Lop (2011:1) and Weedon (1987:29) confirm that the emphasis of post-structuralism on agency and context could offer feminism possibilities for an agenda of change through criticism and the deconstruction and reconstruction of dominant discourses. According to Grosz (1989:xv), the purpose of deconstruction is .... to keep things in process, to disrupt, to keep the system in we create, to fight the tendency for our categories to congeal.'

Feminist post-structuralism adds another layer to post-structuralism.

For feminist post-structuralists what is mostly left out of history, society, government, and education are the lives of wome and they look for the silences that represent women and their stories. They also want to show that what was once thought of as truth is just one way of seeing the world (Hollingsworth
1996:29; Jones 1993:157-167). What feminism contributes to post-structuralism is described by Weedon (1987:20) as addressing ${ }^{\prime} . .$. the questions of how social power is exercised and how social relations of gender, class, and race might be transformed.' According to Barrett (2005:19-27) and Baxter (2002:5), feminist post-structuralism as a mode of knowledge production explains how identities are constructed within societal discourses, and propagates the idea of a feminist agency which resists hegemonic discursive positioning.

According to Weedon (1987:40), feminist post-structuralism uses poststructuralist theories of language, subjectivity social processes and institutions to understand existing power relations and identify areas and strategies for change. The fundamental aspects of feminist post-structuralism(s) that are applicable to this study are the post-structuralist theories of language, subjectivity, power and agency.

\section{LANGUAGE}

The language theory confirms that post-structuralism is a development of structuralism, and seeks to critically 'extend' the insights of structuralism. Post-structuralists radically foreground language, rather than structures, culture, and society which are all interpretations (Barrett 2005:19-27). Derrida (in Macksey \& Donato 1970:247-272) emphasise mediated by language and meaning, and meanings canno be fixed because they are deeply contextual and are shifting endlessly. There exists a range of historically and culturally specific possible meaning(s), and subjects can never get to the final real meaning, or structure of a society, action or text. For post-structuralism, language is a common factor in the analysis of organisations, social meanings, power, and individual consciousness (Weedon 1987:21).

For Weedon (1987:22), language is not reflecting an already given social reality but constitutes and gives meaning to
the social realities for subjects, it becomes a critical site for the contestation of meaning, and offers humans various discursive positions through which they can consciously live their lives. The way humans give meaning to social relations is both fostered and constrained by their access to existing discourses. These discursive fields consist of competing ways of giving meaning to the world, organising social institutions and processes, and offering individuals a range of subjectivity modes (Barrett 2005:19-27; Weedon 1987:26, 35). Foucault (as cited in Butler 1993:23) documented the historically-specific discourses which produced sexuality, and indicated that he did not reveal the 'real truth' about sexuality, but that 'the real sexuality (what sexuality is) is a product of the historically-
specific meaning and discourses (or systems) within which it is enacted, spoken about, or produced.

\section{SUBJECTIVITY}

Contrary to the humanist notion of knowing, knowable, an rational subjects, the post-structuralist theory of subjectivity is viewed as a site of disunity and conflict which are produced 
fixed. Rational, humanist subjects have typically been examined by means of lists of bounded, discrete identity categories that attempt to represent them as rational, stable, and static (Davies argued that humans are not socialised into the social world

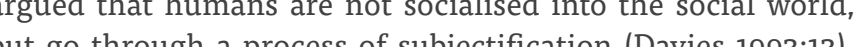
For Davies (1990:501-516), the examining of any individual's For Davies (Igo: subjectivity a way of gaing thess to he constitutive effects as subject, and the world is made real.

The tensions and instabilities in an individual's subjectivity become visible in a poststructuralist analysis through an examination of the discourses and practices through which the subjectivities are constituted. These discourses and practices are often in tension, providing the subject with multiple layers of contradictory meanings which are inscribed in her/his
body and conscious and unconscious mind (Davies 1993:11). According to Jones (1993:157-167), subjectivities are in motion According to Jones (1993:157-167), subjectivities are in motion is not sufficient to refer unproblematically to $\ldots$ '.. giving voice is not sufficient to refer unproblematically to '... giving voice
to experiences, as if this is a source of true knowledge.' All to experiences, as if this is a source of true knowledge. All of subjectivities reveals socially-constructed versions of understanding.

\section{POWER AND AGENCY}

In terms of the power and agency theory, it is important to start with the premise that post-structuralism propagates a different view of power (Letts 2006:624). Weedon (1987:136) contends that power is created by society using history, politics, and the circumstances surrounding events. All socien relationships productive and repressive force. The principles of feminist post-structuralism can be applied to all discursive practices to analyse how they are structured, what power relations they produce and reproduce, and challenge and transform the esistance and weak points (Weedon 1987:136). Agency refers to the ability to respond to a certain response-ability that a subject represents (Letts 2006:623-627). In feminist poststructuralism, the notion of agency is conceived as closely thinked to the process of subjectification, and involves a tension between speaking the self into different subject positions while sinultaned in the discousses through which one becomes a subject. (Barrett 2005:19-27). Post-structural subjects are constantly shifing and changing positioning within the discourses that produce then (Butler 1993.23). They are individuals with an who can exercise free choice, but are constraned by avallable discourses. Post-structuralist gency acknowledges that subjects may take up discourses that dives the anguage and practice produce structure, words, and actions they can be turned against the same structures that they produce (Davies 2000:28).

The subject is produced within contexts, and its agency is enabled and constrained by the same contexts (Letts 2006: 624-626). Davies (1993:12) argues that post-structuralism opens up the possibility of agency to the subject through making visible the discursive threads through which her/his experience as specific being is woven. Agency cannot exist outside of the discursive, since the object claimed to be exempted from discursive production will always require prior delimitation to establish itself outside of discourse (Butler 1993:11). Subjects cannot escape the constitutive power of discourse, because their freedom does not exist outside discourse, but in disrupting the dominant discourses, adopting unfamiliar ones, and making structures visible. Only then can the subjects begin that discourses are social constructions whic are open to the possibility of change (Davies 1994:624- 244 626).

\section{Feminist post-structuralism and education:}

\section{feminist pedagogy and practice}

The answer to the question of what feminist post-structuralism contributes to education, is according to Valero (2004:35) and ways of interrupting abiding educational exclusions an ways of interrupting abiding educational exclusions an education research.

For this study, the focus is on the first-mentioned, namely the utilising of feminist pedagogy to make sense of and identify ways to address and transform gender exclusions and inequalities in the South African education system.

\section{Concepts pedagogy and feminist pedagogy}

Before discussing the premise and practice of feminist pedagogy, the meanings of the concepts pedagogy and feminist pedagogy are provided. Watkins and Mortimore (1999:8) define the concept pedagogy as: '.... a suitably complex model... [which] .. specifies relations between its elements: the teacher, the classroom or other context, content, and view of learning and learning about learning.' This academic model of pedagogy may be distinguished from the practitioner's model of pedagogy. In the practitioner's model, the emphasis is more on the dynamic interrelationships between all the role-players in the learning context, and the numerous influences on learning (Watkins \& Mortimore 1999:1-19). Despite the distinction betwee approach (academic model) and application (practitioner's model), Giroux and Simon (1989:239) describe the concept pedagogy as '... a deliberate attempt to influence how and what knowledge and identities are produced within and amon particular sets of social relations.'

The concept feminist pedagogy originated in the 1980 s as the dominant educational approaches (Crabtree \& Saa 2002:131-140). Feminist pedagogy is a form of critical pedagogy and aligns itself with other forms of critical pedagogy such as race, ethnicity, class, post-coloniahism, and globalisation. It is grounded in the critical theories of learning and teaching, and facilitates participatory learning, validates personal experience, encourages social understanding and activism, and develop critical thinking and open-mindedness (Hoffmann \& Stak 1998:79-97
Feminist pedagogy is also grounded in feminist theory, and includes epistemological assumptions (i.e. power and consciousness-raising, oppression and social transformation), teaching strategies, content approaches, classroom practices, and teacher-student relationships (Crabtree \& Saap 2002:131of learners from passive recipients of knowledge to active of learners from passive recipients of knowledge to active knowers and agents of social change, and feminist teachers and how they teach, and how who they are affects how they teach (Currie 1998:347-360).

\section{Six basic principles of feminist pedagogy}

Webbe, Allen and Walker (2002:1-20) and Weiler (1991: 449-474) identified six basic principles of feminist pedagogy. These principles are the reformation of the teacher-learner relationship, empowerment, community building, voice and the challenging of the traditional pedagogical notions.

The first principle, the reformation of the teacher-learner relationship, is related to the traditional education paradigm's classic relationship between the teacher and the learners, where the teacher is perceived to be an omniscient and authoritative figure and the learner a passive recipient of knowledge. In feminist pedagogy, power and control are shared between the learners and teachers. The classroom becomes an active and collaborative context, where risk-taking and intellectual adventure are encouraged, and power is viewed as energy, capacity, and potential.

Empowerment is the second feminist pedagogical principle, and involves democracy and shared power, and challenges the view that education is a neutral cognitive process. For the proponents of feminist pedagogy, education functions either as an instrument for the facilitation of the learners' integration and conformity into the logic of the present system, or becomes the practice of freedom. This refers to the teaching of both female and male learners to deal critically and creatively with reality, and learn to participate in the transformation of their mmediate context. Freedom emerges through empowerment, feelings, and experiences. The third principle of feminist pedagogy is concerned with the building of community and cooperation within the classroom, and between the classroom and its broader environment. The development of a community of growth and caring is a key pillar of feminist education, and since feminism values community and equality, the building of a trusting environment is at its core. All members are respected and have equal opportunities for participation.

The fourth feminist pedagogical principle focuses on the view that knowledge is constructed and culture-bound. In feminist pedagogy, the learner-teacher relationship is less intimidating and more quitable. Multipleathories (teacerlearner, learner-teacher, learner-learner) allow for different classroon dynamics and voices to emerge (culture-bound). As authority shifts from the teacher to her/his learners, the learners interact and ask questions, and their feedback is actively sought and incorporated into the classroom dynamics (constructed knowledge). The fifth principle of feminis pedagogy refers to an integrated community of learners and teachers that work closely together, respects each other's socio-historical development, challenges the hierarchical relations of schooling and involves social bonding within more democratic relations. For proponents of feminist pedagogy/, the above notions are fundamental to schooling and a forum for critical democracy. Feminist theory also privileges persona lived experiences as the basis for analysis, theory generation, activism, and research, and which results in positive outcomes espect, enhanced empathy, improved critica thinking skills, and a broader understanding of truths.

The final and sixth feminist pedagogical principle is embedded in all five preceding principles. This principle challenges the traditional pedagogical view and practices such as that knowledge and teaching methods can be value free. In terms of social construction of gender through the dichotomisation of nurture and autonomy, public and private, and masculine and nurture and autonomy, public and private, and masculine and feminine. Feminist teachers are also encouraged to challenge
the origins of ideas and theories, the positions of their superiors, and the factors which influence the way knowledge comes to exist in its present form.

\section{Four ways to practice feminist pedagogy}

The purpose of feminist practice is to raise the learners consciousness about patriarchal oppression, empower them to take action, and assist them to learn specific political strategies the learners' a teaching-learning environment is created where those of women and marginalised learners) are respected, the power in the classroom is decentred, and the learners are encouraged to voice their perspectives, realities, knowledge, and needs (Rose 1989:488). Robertson (1994:11-15) listed four ways to empower newly-qualified teachers to implemen feminist pedagogy. They are the decentring of power, active learning, activist projects, and feminist assessment practices.

To decentre power in a classroom is difficult, but, according to Garber and Gaudeluis (1992:12-33), methods such as active learning and activist projects can assist learners to collaboratively create knowledge, question the patriarcha structures, and participate as agents of social change. Feminist teachers empower learners by offering opportunities for active learning such as critical thinking and self-analysis, and the balancing of power between the teacher and learners in the classtoom. This shanng of power creates space for dialogue which reflects among other things the multiple voices and realities of the learners, a more equal position between the teacher and her/ his learners, the learners as knowledge producers, and the decentralisation of the traditiona understanding of learning and assessment (Robertson 1994: 11-15).

According to Dean (1996:239-240) and Rose (1989:478-488) activist projects encourage learners to identify real life examples of unfairness and oppression, take action against them, and recognise the potential of feminist discourse outside

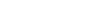


of the academic context. The activist projects can take a variety of forms, such as the organisation of letter writing campaigns for fairness and accuracy in media reporting, groups of learners aich conditions of women in Africa.

Literature on feminist assessment practices is sparse, possibly because of the incongruity between the notions of feminism and assessment. Nonetheless, the feminist pedagogy literature includes examples of possible feminist assessment techniques. These techniques decentre the power structure of the traditional assessment system and focus on learner voice and experience, which provide the learners with agency as they participate in the assessment process. The use of journaling and participatory evaluation(s), which are characterised by interactivity and trust, is considered to be pedagogically sound feminist assessment techniques (Hutchings in Musil 1992:1738). Assessment techniques borrowed from critical pedagogy can also be considered as suitable feminist assessment can also be considered as suitable feminist assessment approaches and techniques. These include learners who are or self-assessment activities (Price, O'Donovan \& Rust 2007: 143-152). Accardi (2013:79, 83-87) argues that feminist 143-152). Accardi (2013:79, 83-87) argues that feminist
assessment approaches can also be embedded into more traditional forms of assessment if learners reflect on, or evaluate, their learning experiences using product or performance assessment techniques. Debating, interviewing, and focus group discussions can be considered as appropriate assessment methods for feminist pedagogy, provided that the learners' voice or knowledge are sought (Keesing-Styles 2000:1-5).

\section{A different teacher education: Applying feminist} pedagogy to the education of pre-service teachers

As indicated in the problem statement of the study, most student teachers teach as they themselves were taught, and one way to break the cycle of the male-dominated, hierarchical pedagogies is to transform the initial teacher education (ITE) system by introducing student teachers to feminist pedagogy (Arends 1999:41). According to McGuinness (2009:339-349) and Robertson (1994:11-15), a feminist teacher is a teacher who works consciously to dismantle hierarchical structures and foster community within the classroom; awaken learners to the oppression of women and other minority groups; engage learners in active discussion; put teaching into the context of the learners' lives and experiences; and empower learners with the understanding that knowledge is not neutral, but a merging of the personal, social, and political. According to Robertson (1994:11-15), prospective teachers need to be immersed in eminist pedagogy, not only in the disciplines, but also in the teacher education modules, and this transformation should begin within governmental guidelines and requirements for teacher certification

For those teacher educators who aspire to include aspects of critical and feminist pedagogy in their pre-service teacher education modules, this article is concluded with a discussion of an exemplar pre-service teacher education module entitled, A the modul is intended for pre-service Further and Education Trainin PGCE (Postgraduate Certificate of Education) progr the BEd overall aim of the module is threefold namely to sensise the student teachers to the diversity of cultures and life prise the in their future clossrooms, encourage them to be pactices ntheir future classtoons, encourage them to be facilitators applicability of the learners' own experiences (MCGyiness 2009:339-349).

Given the aim of the module, the module is divided into three sections. In Section A entied Bringing feminist pos structuralism to bear on teacher education the usefulness of feminist post-structuralism is demonstrated to the student teachers in order for them to generate personal and professional agency, and make sense of and interrupt th abiding educational exclusions and inequalities. To this end the concept of feminist post-structuralism and its principles of language, subjectivity, power, and agency are to be introduced to the student teachers as a means to successfully handle and address any possible gender tension and conflict during their teaching practice period, and beyond.

The student teachers are also to interrogate, in groups of six a vignette which deals with Casey who was enrolled for the Subject Didactics Mathematics module(s), and introduced to both the normative constructions of mathematics [education] and the gender gap in mathematics achievement. For this purpose, the student teachers is expected to individually read an article (Letts 2006:623-627) dealing with the gender inequity debate in Mathematics, and how to reconstruct the subject to include all people. The student teachers then have to compile individual narratives in which they apply the feminis post-structuralist principle of subjectivity to the content of the vignette (Wedge 2007:251-260)

Section B of the module deals with the theme, Critical pedagogy in the classtoom and school. In this section, the student teachers are provided with critical thinking skills to be sensitive to cultural differences (race, ethnicity, gender, sexuality, an class), and promote democracy, equity, and social justice in their future classrooms and schools. To achieve this, they are to be introduced to the critical pedagogy literature, with specia reference to its central tenets (P. Freire and I. Shor), how it has evolved over time (b. hooks and R. Simon), and the critique within and dected towards it (C.A. Bowers, N. Burbules, H. Giroux, J. Gore, P. McLaren, and S. Parker). The focus is, however, on the feminist perspective (E. Elsworth \& H. Weiler).

For Section C of the module entitled, Feminism: education pedagogy and practice the student teachers are to stat with a study of the background to and short history of the development of feninism and gender in educhen, followed by an exploration of the arguments for the adoption of feminist pedagogy to promote gender-equitable practices in the classroom, school, and beyond. The focus in this section is initially on knowledge of the con feminist pedagogy, it six basic pedagogical principles, four of the ways to practic feminist pedagogy in the classroom, and feminist assessment practices.

The attention then turns to two interrelated contexts which are important for successful feminist teaching, namely authentic dialogue between the learners and teachers as equally knowing subjects, and the social reality of the learners (Freire 1984:49). In this section, the student teachers, in groups of 4 , are to design an activist project for Grade 10 learners. The project has to include the following: the activities, and a launch strategy. For connected and constructed feminist pedagogical knowing learning context (teaching practice schools) which will eventually culminate in individual reflective journals of their practicum experiences, with reference to a few female tales.

As concluding activity for this section, the student teachers are to individually com-pile an essay using the topic: Talking relevance an alternative teacher education for South Africans! The purpose of the activity is for the student teachers to acknowledge that their study of the feminist pedagogy module occurred within a feminist classroom setting. As background information for this activity, the student teachers are to study two chapters (Chapters 8 and 9) from the book Women's Ways of Knowing authored by Belenky, Clinchy, Goldberger and Tarule (1986), which introduces them to women's pedagogy.

In Section $\mathrm{D}$, the student teachers are to create individual learning portfolios. A learning portfolio is a flexible tool which engages student teachers in a process of continuous reflection and collaboration on selective evidence of learning. This section is modelled on Zubizarreta's (2004:1) simple learning portfolio model which consists of three components, namely reflection, documentation, and collaboration.

The learning portfolios of the student teachers are to contain the following assessment evidence: individual written narratives on Casey's vignette (Circle, 1 Reflection), individual practicum reflective journals (Circles 1 and 2, Reflection and Documentation), group activist projects (Circle 3, Collaboration and Mentoring), and individual "Talking relevance ..." essays (Circle 2, Documentation).

Refer to Figure 1 below for a schematic representation of the assessment procedure for the module.

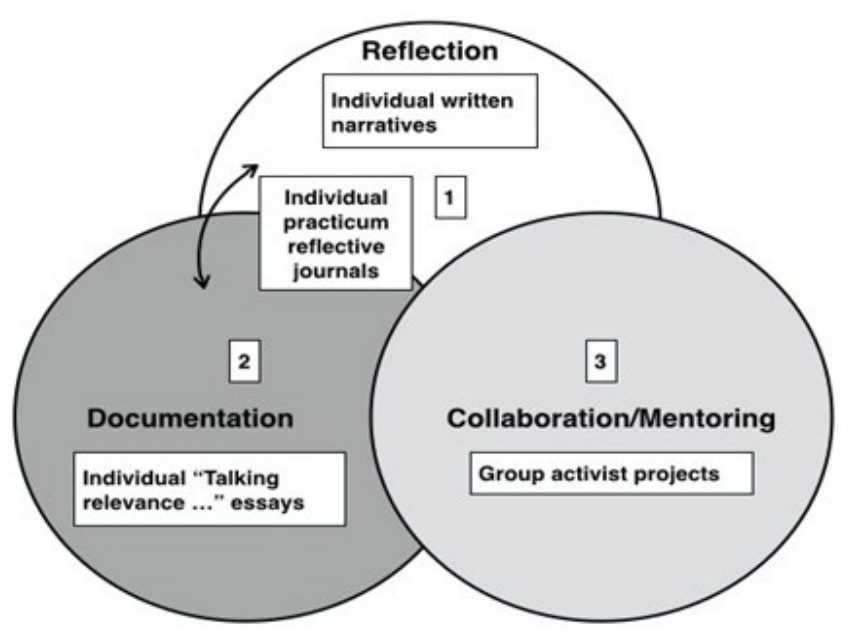

Figure 1: The individual learning portfolio assessment procedure for

\section{CONCLUSION}

In this study, the case for feminist pedagogy as a new initiative in the education of South African teachers was argued. It was demonstrated that South African teachers could be educated to be agents of social change to transform South African learners from passive recipients of gendered knowledge to active agents discourse, and open up space for plural interpretation and gender-fair perceptions.

Very little research has been published in South Africa about feminist tales of teacher preparation for certification. This article was an attempt to promote the standing of feminist teacher education research in South Africa. The value of poststructuralism was demonstrated as an eclectic theoretical framework which can be utilised by educational researchers to not only problematise the relationship between gender and teacher education, but also examine and re-examine the relationship from a variety of perspectives. These perspectives will allow for contradictions and resistance, a multiplicity of positioning within the context of interaction, and the voice of the researchers to emerge. In response to Francis' (1999:387) argument of '... whether a theory which deconstructs other theories, but appears to provide nothing with which to replace them, can be relevant ....", it was illustrated that feminist poststructuralism is much more than an effective tool with which to deconstruct the cultural processes responsible for constituting structures of oppression in pre-service teacher education programmes, but that it provides a way of understanding the world through a plurality of voices and perspectives. This may result in greater recognition and connection between people of competing vievoints, and social and educationa transformation in South Africa. Feminist post-structuralis analyses have yet to be used widely by female and other gender-conscious educational researchers in South Africa, and relatively few research reports of good practice to guide researchers havebeen contributes to the difficulty of arguing the logic of combining feminism with teacher education in South Africa, and 
persuading a cynical readership of its value as an alternative teacher education paradigm.

To turn things around, this study is concluded with two generic recommendations:

Increased scholarship in feminist pedagogy and teacher education: This is one of the ways to break away from the conventions of traditional teacher education and practice. To assist South African teacher educators who want to make strategic gender interventions across a range of educational aspects - from policy analysis to pedagogy, and research to the field experience - it is recommended that the topic, Feminist teacher education and pedagogy: the theories, scholarship and practice, be a standing theme on national and international conference programmes. The conference papers should then be submitted to the international journal, Feminist Teacher to disseminate more nationally and internationally.

Innovation and evolution of initial teacher education: For teacher educators who want to step out of the traditional teacher education paradigms where student teachers are told how to teach, to practices where student teachers' consciousness about patriarchal oppression are raised, they are empowered to take action, and informed of how to design strategies for activism. it is recommended that initial teacher education programmes should do much more than cross borders in schools with knowledge of gender in education. Student teachers have to be empowered to be agents of gender change within the context of the 'sedimented' (hegemonic and patriarchal) school culture in South Africa.

\section{With the above in mind, this study is concluded} with the following:

Beliefs and ideologies are ... unconscious. They become habits and as such, an automatic part of our speech, our way of thinking and behaving. For this reason it is very difficult to alter beliefs. It is here that the education system can play a crucial role. ... teachers should be trained to put an end to the sexual inequity in education (Department of Education, 2002:21|.

\section{REFERENCES}

Accardi, M., 2013, Feminist pedagogy for Library instruction, Library Juice Acade-
my, Sacramento, CA.

Apple, M., 1988, Teachers and texts: a political economy of class and gender rela tions in education, Routledge \& Kegan Paul, New York.

Arend, S.F., 2007, The Employment Status of Educators, HSRC, Pretoria

Arends, R., 1999, Learning to Teach, McGraw Hill, New York.

Author, 2013, Theme 1: Identity and belonging session, attended at the 14th public, 9-11 July.

Barrett, M.J., 2005, 'Making (Some) Sense of feminist Poststructuralism in EnvironEducation, 10 (Spring), 19-27.

Baxter, J., 2002, 'A juggling Act: A feminist post-structuralist analysis of girls' and boys' talk in the secondary classroom', Gender and Education in the secondary classroom, 14(1), $5-19$.

Belenky, M.F., Clinchy, B.M., Goldderger, N.R., \& Tarule, J.M., 1986, Women's Ways of Knowing, the Development of Self, Voice, Mind, Basic Books, New York.

Branston, G. \& S Stafford, R., 2001, The Media Student's Book, Second Edition, Routledge, London, New York.

Sh, 0., 2003, Practice makes Practice: A critical study or learning to teach State University of New York Press, Albany, New York.

Butler, J., 1993, Bodies that matter: On the discursive limits of sex, Routledge, New

Cohee, G., 2004, 'Feminist Teaching', The Teaching Exchange 9(1), 1-4.

Crabtree, R., \& Saap, D., 2002, 'Theoretical and Pedagogical Challenges in the 131-1 140

Currie, D., 1998, 'Subject-ivity in the classroom. Feminist meet Academe', Canadi(n)

Davies, B., 1990, 'The problem of desire', Social problems 31(4), 501-516

Davies, B., 1993, Shards of glass. Children reading and writing beyond gendered identities, Allen \& Unwin, Sydney.

Davies, B., 1994. Poststructuralist practice: theory and classroom practice, Deakin University, Victoria.

Davies, B., 2000, A body of writing, Rowan \& Littlefield, Oxford

Dean, R., 1996, 'Discourses in South Africa: rethinking critical pedagogies in post-Modernity', Discourse in the cultural politics of education 17(2), 239-240.

Department of Basic Education, 2011, National Curriculum Statement (NCS)

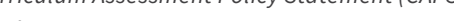

Department of Education, 2002, Issues on gender in schools an introduction for teachers, Government Printer, Pretoria

Derrida, J. 1970, 'Structure, sign and play in the discourse of the human sciences' man: The structuralist controversy, Johns Hopkins University Press, Baltimore.

De Vos, A.S., Strydom, H., Fouche, C..B., \& Delport, C.S.L.L., 2011, Research at Grass Roots. For the Social Sciences and Human Services Professions, Fourth EdFardon, J.J.V., 2007, 'Gender in History teaching resources in South African public

Fardon, J.V.V., \& Schoeman, S., 2010, 'A feminist-post structuralist analysis of an exemplar South
30(2), 307-323.

Francis, B., 1999, 'Modernist reductionism or post-structuralist relativism: Can we move on. An evaluation of the arguments in relation to feminist educational move on. An evaluation of the arguments
research', Gender \& Education 11,381-393.

Freire, P., 1984, Pedagogy of the Oppressed, Continuum, New Yonk

Garber, E., \& Gaudeluis, Y., 1992, 'object into subject: Feminism, art, education and the construction of self', Canadian Journal of Art Education 19 (1), 12-33.

Giroux, H., \& Simon, R., 1989, 'Popular Culture and Critical pedagogy. Everyday life as a basis for curriculum knowledge', in, H. Giroux \& P. McLaren (eds.), Critic

Gouws, A., \& Hassim, S., 2014, 'Who's Afraid of Feminism? South African Democracy at 20: An introduction', Agenda, 28(2), 2-4.

Grosz, E., 1989, Sexual subversions: Three French Feminists, Allen \& Unwin, Sydney Hoffman, F., \& Stake, J., 1998, "Feminist Pedagogy in Theory and Practice. An empirical investigation', NWSA Journal 10(1), 79-97. Hollingswworth, S., 1996, Teacher Research and Urban Literacy Educatitinn: Lessons
and Conversations in a Feminist Key, Teacher College Press, New York.

Hooks, B., 1994, Teaching to

Hutchings, P., 1992, 'The Assessment Movement and Feminism: Connection or collision?, in, C.M. Musil, (ed.), Students at the center: Feminist assessment, Washington, DC.

Jones, A., 1993, 'Becoming a girl: post-structuralist suggestions for educational research', Gender \& Education 5, 157-16

Keesing-Styles, L., 2000, The Relationship between Critical Pedagogy and Assessment in Teacher Education,
issues1/ 0/ 3 keeesing-styleshtm

Lather, P., 1991, Feminist Research in Education: Within/Against, Deakin Universit Press, Geelong, Australia

Letts, W., 2006, 'Bringing feminist poststructuralism to bear on (mathematics) 'eacher education', paper presented at the 29 th Annual Conference of the
Mathematic Education Research Group of Australia, Canberra, Australia, 22-27 August.

Lop, P., 2011, 'What is feminist post-structuralism?', Helium. Where knowledge rules, ht t p p://w w w.h eliu m.com / it em s/2092463-w h a t-is-feminis post-structuralism.

Maree, K., Creswell, J.W., Ebersöhn, L., Eloff, I., Ferreira, R., Invankova, N.V.

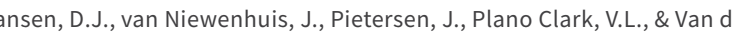
Westhuisen, C.., 2012, First steps in research, Van Schaik, Pretor

McGuiness, M., 2009, 'Putting themselves in the picture: using reflective diaries in $3(2), 339-349$.

McLaren, P., 2000, 'Paulo Freire's Pedagogy of possibility', in, S. Steiner, H. Kranak, P. McLaren \& R. Baruth (eds.), Freirean Pedagogy, Praxis and Possibilltwess

P. parative studies', in R.G. Paul ston, (ed.), Carthography: Mapping ways of seeing social and education sciences, Garlon, New York. ice, M., O’Donovan, B., \& Rust, C., 2007, ‘Putting a social constructivist assessmentroess model into practice. building the feedback loop into the assessInternational, 44(2). 143-152.

Robertson, L., 1994, 'Feminist Teacher Education. Applying Feminist Pedagogies 11-15.

.

Rose, s., 1989, The protest as a teaching techinique for promoing feminist activ ism', NWSA Journal, 487-488.

choeman, S., 2012, 'The representation of women in a sample of post-1994 South African s

Shor, I., 1996, When students have power, University of Chicago, Chicago.

Valero, P., 2004, 'Postmodernism as an attitude of critique to dominant mathematics education research', in M. Walshaw,
postmodern, Information Age, Greenwich.

Watkins, C., \& Mortimore, P., 1999, 'Pedagogy: What do we know?', in P. Mortimer (ed.), Understanding Pedagogy and its impact on learning, Chapman, London.

Wedge, T., 2007, 'Gender perspectives in mathematics education: intentions of

Webbe, L.M., Allen, M.W. \& Walker, K.L., 2002, 'Feminist pedagogy: Identifying Basic Principles', Academic Exchange Quarterly 6(1), 1-20.

eedon, C., 1987, Feminist practice and poststructuralist theory, Basil Blackwe

Weiler, K., 1991, 'Freire and Feminist Pedagogy of difference', Harvard Educational Review 61(4), 449-474.

Weiner, G., 2004, 'Learning from feminist education, pedagogy and practice, for Gender Equity and Quality Basic Eduction in schools, Nairobi, Kenya, $2-3$

Youdell, D., 2006, "Diversity, hequality, and post-structural politics for education" Discourse, 27(1), 33-42.

Zubizarreta, J.T, 2004, The Learning Porttolio: Reflective practice for improving student learning, Anker, MA. 